О. В. Шеремет

\title{
СПОЛУЧУВАНІСТЬ І СИНТАКСИЧНІ ФУНКЦІЇ ДІЄСЛІВНИХ ЛЕКСЕМ (НА МАТЕРІАЛІ «ІСТОРІї УКРАЇНСЬКОÏ ЛІТЕРАТУРИ» М. ГРУШЕВСЬКОГО)
}

Шеремет О. В. Сполучуваність і синтаксичні функції дієслівних лексем (на матеріалі «Історії української літератури» М. Грушевського).

Стаття присвячена синтагматичному рівню системного вивчення лексики. У ній розглядаються закономірності семантико-синтаксичної сполучуваності дієслів, досліджується зв'язок між валентністю, синтаксичними функціями та позицією лексичних одиниць у реченні.

Ключові слова: дієслово, валентність, позиція, предикат, синтаксична функція, сполучуваність, закономірності синтаксичних зв'язків.

Шеремет Е. В. Сочетаемость и синтаксические функции глагольных лексем (на материале «Истории украинской литературы» М. Грушевского).

Статья посвящена синтагматическому уровню систематического изучения лексики. В ней рассматриваются закономерности семантико-синтаксической сочетаемости глаголов, исследуется связь между валентностью, синтаксическими функциями и позицией лексических единиц в предложении.

Ключевые слова: глагол, валентность, позиция, предикат, синтаксическая функция, сочетаемость, закономерности синтаксических связей. 
Sheremet $\mathrm{O}$. V. The combinations and syntactic functions of the verbal lexemes (on the material of «The history of the Ukrainian literature» by M. Grushevsky).

Article devoted to the syntagmatic level of systematic study of lexical. Appropriateness of syntaxical connection between valency, syntactic functions and positions of lexical units in the sentences is examined in it.

Key words: verb, valency, position, predicate, syntaxical functions, combination, appropriateness of syntaxical connection.

Синтагматика дієслівних лексем - лінгвістичне явище, що гносеологічно пов'язане 3 лексикологією, семантикою й синтаксисом, оскільки лексеми розглядаються як контекстно впорядковані лінійні одиниці, що функціонують у мовленні. Дієслівні лексеми $є$ одними 3 найбільш досліджених у синтагматиці, оскільки вивчення теорії сполучуваності розпочалося саме з розгляду сполучувальних властивостей дієслова як центру речення. В. Гумбольдт визначав дієслово як нерв мови: «усі інші слова в реченні як мертвий матеріал, який чекає свого з’єднання, і лише дієслово є сполучною ланкою, що містить у собі й поширює життя. Думка, образно кажучи, завдяки дієслову залишає свою внутрішню оселю й переходить у дійсність» [4, с. 199]. Після виходу у світ книги «Нарис структурального синтаксису» Л. Теньєра теорія вербоцентризму зміцнила свої позиції в зарубіжній лінгвістиці, стала широко використовуватися в дослідженнях європейських мов, у яких дієслово $є$ обов'язковим компонентом речення. В українському мовознавстві провідною стала суб'єктно-предикатна теорія, проте вітчизняні науковці не залишають поза увагою організуючу роль дієслова в семантичній структурі речення.

Дієслівні лексеми з огляду на їхні сполучувальні й реченнєвотвірні можливості досліджували Ю. Д. Апресян, Н. Д. Арутюнова, Ф. С. Бацевич, Л. М. Васильєв, І. Р. Вихованець, В. Г. Гак, Б. М. Гаспаров, К. Г. Городенська, А. П. Загнітко, Г. О. Золотова, Н. Л. Іваницька, . П. Кочерган, О. С. Мельничук, І. І. Мєщанінов, В. М. Русанівський, Л. Теньєр, Н. Ю. Шведова та інші. Вивчаючи сполучуваність у синтаксичній системі, науковці збагатили типологію синтаксичних зв'язків, поглибили вчення про синтагматичні властивості лексичних одиниць. Упродовж останнього десятиліття українські мовознавці: О. М. Галаган, А. С. Джура, І. В. Жигора, В. М. Каленич, Г. В. Кутня, О. В. Куц, О. Ф. Ледней, О. І. Леута, Т. С. Масицька, О. Г. Межова, Н. І. Романець, - активно досліджували валентнісні властивості дієслів.

Комплексне дослідження сполучуваності й синтаксичних функцій дієслівних лексем у сучасному мовознавстві зумовлене потребою вивчати мову як ієрархічно організовану органічну єдність різних підсистем. Об'єктом розгляду пропонованої статті виступають валентнісні потенції та синтаксичні функції дієслівних лексем. Метою роботи є дослідження зв'язку між сполучуваністю й синтаксичними функціями дієслівних лексем. 
У мовленні дієслова функціонують не ізольовано, а в певному контекстному оточенні, тому значення кожної лексеми залежить від іiі семантико-синтаксичної позиції. Між поняттями «позиція», «функція» i «валентність» існує тісний зв’язок. І. Р. Вихованець розглядає синтаксичну функцію як «роль, призначення синтаксичних одиниць i граматичних засобів у побудові зв'язного мовлення» [12, с. 595]. В. Г. Гак теж відзначає, що «для мови функція зрештою пов'язана з комунікацією, бо лише завдяки комунікації мова продовжує існувати і розвиватися» [3, с. 7]. Синтаксична функція і позиція співвідносяться як поняття загального і конкретного рівня абстракції: той чи той тип функції кожна синтаксема реалізує в певній синтаксичній позиції в тій чи тій моделі речення або словосполучення. Звідси випливає діалектична єдність функції і позиції, 3 одного боку, функція мовної одиниці реалізується в певній позиції, 3 іншого, - позиція визначає функцію цієї одиниці. У рамках функціональної граматики поняття функції співвідноситься 3 парадигматикою i синтагматикою як середовищем функціонування. А синтаксична позиція, що знаходиться на перехресті парадигматики і синтагматики, регулює зв'язок між одиницями й створює умови для їх об'єднання. «Позиційний шлюз» обмежує можливості вираження того чи того компонента в реченні: парадигматичний ряд форм, що займають ту чи ту позицію в системі речення, зумовлений синтагматичними властивостями, тобто властивостями системи [8, с. 50]. Осмислення синтаксичних функцій дієслівних лексем у синтагматичному аспекті спричинило потребу в розкритті їх граматичних властивостей і здатності поєднуватися з різними поширювачами в реченні. Цю властивість дієслівних лексем Л. Теньєр означив терміном «валентність». Уведення нового, запозиченого 3 хімії, поняття було логічним продовженням теоретичного вивчення синтаксичних функцій дієслова й інших структурних компонентів речення як здатності слів вступати в синтаксичні зв’язки з іншими мовними одиницями.

Валентність, згідно з трактуванням Л. Теньєра, - це здатність дієслова сполучатися з певною кількістю актантів - діючих членів і сирконстантів обставинних членів речення - при побудові висловлювання. «Дієслово можна собі уявити у вигляді своєрідного атома 3 гачками, що може притягувати до себе більше чи менше число актантів, залежно від більшої чи меншої кількості гачків, якими він володіє, щоб утримати ці актанти при собі» [11, с. 250]. Основоположник теорії валентності вважав, що той, хто здійснює дію, є «першим учасником»; той, що відчуває на собі дію «другим»; а компонент, якому адресовано певний процес - «третім». Кількість можливих семантичних ролей актантів обмежена, проте серед лінгвістів немає однозначного погляду щодо їхньої конкретної кількості (від 8 до понад 40 ролей). На основі здатності дієслів об'єднуватися 3 різною кількістю актантів Л. Теньєр диференціював їх на чотири підгрупи: авалентні, моновалентні, двовалентні й тривалентні. І. Р. Вихованець 
стверджує, що «у сучасній українській мові семантично елементарне просте речення передбачає у своєму складі шестивалентні, п’ятивалентні, чотиривалентні, тривалентні, двовалентні й одновалентні предикати. Це означає, що максимальна кількість іменників в елементарному простому реченні не може виходити поза межі шести компонентів, а мінімальна кількість обмежується одним компонентом» [1, с. 124]. А. П. Загнітко виділяє навіть семивалентні дієслова. Проте «погляд Л. Теньєра, - вважає O. I. Леута, - точніше відображає передбачуваність семантичних позицій, бо обставинні детермінанти, навіть якщо вони програмуються семантикою предиката, виконують у реченні роль, відмінну від ролі актантів. Частіше ж обставини, які в семантичному плані являють собою згорнуті предикати, можуть бути відсутніми в реченні або ж входити до структур у необмеженій кількості» [9, с. 28].

У сучасному мовознавстві валентність розглядається як «здатність слова визначати кількість i якість залежних від нього словоформ, зумовлена його семантичними і граматичними властивостями» [12, с. 62]. Уперше вона з'явилася, а деякими мовознавцями й досі розглядається як властивість, що притаманна виключно дієслову. Так, услід за I. Р. Вихованцем, Т. С. Масицька наголошує, що ознакові слова - це «єдині носії валентності», «маємо на увазі насамперед дієслова» [10, с. 9]. На думку дослідниці, «дієслово здатне регулювати кількість семантично залежних позицій, які відповідно заповнюються залежними контекстними партнерами» [10, с. 9], тоді як «інші носії валентності (наприклад, прикметники, прислівники та іменники) набувають валентних властивостей у зв'язку 3 дієсловом, тобто внаслідок їх переміщення в первинну для дієслова предикативну позицію» [1, с. 123]. Предикат визначає структуру пропозиції: «вказує на характер ситуації (позначає дію, процес, стан або якість предмета) і на відповідні місця для предметів учасників ситуації (актантів, аргументів), зумовлює їх кількість і семантичні функції (ролі)» [1, с. 122]. А отже, проблема морфологічної віднесеності граматичної категорії валентності залишається не вирішеною, «бо ні представники напряму, який кваліфікує валентність як виняткову особливість дієслова, ні їхні опоненти, які переносять валентність на інші частини мови, не змогли переконливо довести правильність свого підходу до розгляду цієї проблеми» [9, с. 27]. Більше того, окреслена проблема ускладнюється, адже сьогодні мова йде «навіть про валентність окремих форм слова» [9, с. 27]. Однак і при вербоцентричному, і при суб'єктнопредикатному підходах дієслово завжди залишається в центрі уваги, оскільки саме дієслово як головний носій валентності відбиває сутність предиката. У свою чергу, активна валентність предиката детермінує кількість і характер актантів, а також особливості семантико-синтаксичних відношень, що виникають між ними. Межа між семантикою дієслова i семантикою речення дуже тонка, проте переоцінювати роль предиката теж 
не варто. Дієслівна лексема не здатна визначити повний склад компонентів майбутнього висловлювання, до того ж дієсловам властива різна прогнозуюча здатність.

За ступенем семантичного наповнення дієслова поділяють на абсолютивні (автосемантичні) i релятивні (синсематичні). «Клас абсолютивних дієслів формують лексичні одиниці, семантичне наповнення яких є достатнім. Своїми внутрішніми потенціями ці слова не прогнозують позицій для заповнення їх словами-конкретизаторами. Співвідношення абсолютивних дієслів із реаліями позамовної дійсності забезпечується їх власним фонемним складом» [6, с. 269]. Це не значить, що абсолютивні дієслова не можуть поширюватися іншими словами, просто таке поширення не $є$ обов'язковим. Абсолютивними, наприклад, $є$ дієслова: бліднути, злословити, пахнути, иявісти. На відміну від них релятивні дієслова не можуть «самостійно реалізувати закладений у них зміст» [7, с. 58], тому вони прогнозують семантичне й граматичне заповнення позиції після них граматичними формами, які на рівні підрядних словосполучень «утворюють семантико-граматичні єдності слів» [7, с. 58]. Наприклад: турбуватися про що-небудь, надокучати кому-небудь, здобувати що-небудь, кого-небудь. У реченні «Дід» при тім звичайно не виявляє ніякої енергї̈ для оборони покривдженої (Т. 1, с. 320) до групи релятивних належить дієслово виявляти. Релятивні дієслова переважають абсолютивні як у лексичному складі мови, так і в мовленні. Але між ними немає чіткої межі, бо за семантичною ознакою повноти / неповноти можуть різнитися не лише певні групи слів чи окремі слова, але й «різні значення одного слова» [5, с. 43].

Дієслово $є$ носієм динамічної ознаки, тому «семантико-граматичну природу дієслова як частини мови відбиває його функціонування тільки в позиції присудка або головного члена односкладних речень, співвідносного із присудком. У цих формально-синтаксичних позиціях виявляється категоріальна сутність дієслова, тобто функціональна спроможність основних дієслівних категорій способу, часу i виду» [2, с. 87]. Але тут варто пам'ятати про те, що до вихідної парадигми дієслова належить п'ять докатегорійних дієслівних утворень: 1) дієвідмінюване дієслово (лат. verbum finitum); 2) дієприкметник; 3) дієприслівник; 4) інфінітив; 5) предикативні (присудкові) форми на -но, -то. Дієвідмінюване дієслово виражає взаємозв'язок дії з її виконавцем або сприймачем - реальним чи гіпотетичним, лише йому притаманні семантичні, морфологічні й синтаксичні ознаки дієслова в повному обсязі. Це дає підстави вважати дієвідмінювані форми - типовими, основними дієслівними лексемами. Виконуючи синтаксичну функцію присудка чи головного члена односкладного речення, дієслово «містить у собі макет майбутнього речення i програмує набір позицій для семантичних наповнювачів» [9, с. 25]. Наприклад, у реченні 3 сього погляду в кожній 
казиі мусить бути своє $i$ чуже - теорія запозичення простягає руку теорії самостійности (самозарожденія) (Т. 1, с. 333) синтаксичну функцію присудка виконує особове дієслово простягає. Його активна валентність прогнозує у реченні дві обов'язкові семантичні позиції для суб'єкта і об'єкта. Роль суб'єкта і синтаксичну функцію підмета виконує іменне словосполучення (теорія запозичення), а роль об'єкта i синтаксичну функцію додатка виконує іменник рука у формі знахідного відмінка однини.

Дієприкметник i дієприслівник належать до нетипових дієслівних утворень. «Дієприкметник - змінне, похідне від дієслівних часових форм граматичне утворення, вербоїд, якому властиві ознаки дієслова i прикметника» [12, с. 153]. Типовою синтаксичною функцією дієприкметника є означення, але субстантивуючись, він може виконувати функцію підмета або додатка. Наприклад, у реченні Защіплені в Києві нові культурні парости розростались $і$ иявіли довго потім, як потемнів блиск його золотого столу, як здесяткувались його полки $i$ половецькі орди наступили на торговельні артерії, щзо зносили сюди «жир» цілої Руси (Т. 2, с. 6) дієприкметник защіплені виконує синтаксичну функцію означення. У реченні Потоками сльози проливаються тут вірними, навіть закам'янілий серцем тоді може просльозитись (Т. 1, с. 128) дієприкметник закам'янілий разом з іменником серцее в орудному відмінку однини утворюють стале словосполучення i виконують синтаксичну функцію підмета. Цю синтаксичну позицію зумовлює одновалентний предикат, граматичне значення якого передає граматична форма складеного дієслівного присудка, вираженого допоміжним дієсловом може й основним дієсловом просльозитись. У реченні Вся процедура поставлена під охорону релігї; на кождий акт, на кожду церемонію дають благословенне староста і батьки (їх функиї часто спливають ся), i покликуєть ся поміч вишніх сил, опікунів роду $і$ родини (Т. 1, с. 239) дієприкметник поставлена виконує синтаксичну функцію присудка. «Дієприслівник - незмінне, похідне від дієслівних часових форм граматичне утворення (вербоїд), якому притаманні ознаки дієслова i прислівника. В українській мові найвиразнішою морфологічною дієслівною ознакою дієприслівника $є$ категорія виду. Прислівникова сутність дієприслівника виявляється в його незмінності й синтаксичній функції обставини» [12, с. 155]. Наприклад, у реченні $A$ деякі «скептики» $и$ доводили, щуо Слово сфабриковане на взірецьь Осіана якимсь добродієм, який думав по франиузьки, складаючи сю поему (Т. 2, с. 172) дієприслівник складаючи разом із залежними від нього компонентами: займенником сю й іменником поему, утворює дієприслівниковий зворот, що виконує синтаксичну функцію поширеної обставини. Слід зауважити, що окремі лінгвісти розглядають дієприслівники i дієприкметники у складі прислівників і прикметників відповідно. «Інфінітив - дієслівне утворення, 
що називає дію або процесуальний стан (бігти, писати, мовчати) без вказівки на спосіб, час, особу, число і рід» [12, с. 228]. Об'єктний та суб'єктний інфінітиви здебільшого $є$ формами релятивних (синсемантичних) дієслів, які для реалізації своєї семантики вимагають обов'язкових поширювачів із визначеним семантико-граматичним значенням. У реченні інфінітив найчастіше виконує синтаксичні функції підмета, повнозначної частини складеного дієслівного присудка, рідше іменної частини складеного присудка, роль головного члена інфінітивного речення, додатка, означення та обставини мети. У філологічному тексті кінця XIX - початку XX століття спостерігається дещо інша тенденція: інфінітив найчастіше вживається у складі складеного дієслівного присудка. Наприклад, у реченні Тому для орієнтовання в літературній творчости сеї доби ми повинні почати з сеї памятки (Т. 3, с. 142) інфінітив почати є повнозначною частиною складеного дієслівного присудка. Інфінітив, утворюючи аналітичну форму майбутнього часу дієслова, може виконувати синтаксичну функцію простого присудка. Такими присудками виступають, наприклад, інфінітиви збирати, обтикати і пізнавати разом із допоміжним дієсловом бути: $М и$ будемо ті слідочки збирати, будем васильчиками їх обтикати та по тих слідочках вас будемо, мамко, пізнавати! (Т. 1, с. 129). Відкіля тебе виглядати? (Т. 1, с. 129) - головний член інфінітивного речення. Речення, де інфінітив виконує синтаксичну функцію підмета, а також речення, у яких він $є$ іменною частиною складеного присудка, в «Історії української літератури» М. Грушевського мають меншу частотність: Віддавати $\boldsymbol{c} \boldsymbol{g}-$ бристи через воду, посватити - перенести дівчину через воду, оженити ся-зловити вінець дівчини, переплисти - одружсти ся, утопити ся не одружнити ся (Т. 1, с. 264). Неозначена форма дієслова може виконувати синтаксичні функції другорядних членів речення. Наприклад, у реченні Сей автор, визначаючись незвичайним талантом $i$ високим почутем краси, задумав прославити похід близького йому князя Ігоря на половиів (Т. 2, с. 176) інфінітив прославити виконує синтаксичну функцію обставини мети. Предикативні (присудкові) форми на -но, -то за своєю семантикою та синтаксичним уживанням близькі до дієвідмінюваних форм. Це «незмінні слова, які означають стан і вживаються у функції співвідносного 3 присудком головного члена односкладного речення» [12, с. 519]. Наприклад, безособова форма дієслова толковано виконує синтаксичну функцію співвідносного 3 присудком головного члена в односкладному реченні Клюки толковано як «хитрість» (Т. 2, с. 188). У цьому разі валентність безособового дієслівного предиката зумовлює дві обов'язкові синтаксичні позиції для додатка й обставини. У реченні $3 a$ mе нову віру і иеркву зроблено нешкідливою з соиіального погляду (Т. 2, с. 19) дієслово зроблено і прикметник нешкідливою виконують синтаксичну функцію співвідносного зі складеним іменним присудком головного члена 
односкладного безособового речення. Безособова форма на -но, -то вживається замість пасивного дієприкметника, аби наголосити на дії, а не на ознаці. Безособова форма дієслова може бути частиною головного члена, співвідносного зі складеним дієслівним присудком. Так, дієслівна форма пробувано є частиною головного члена пробувано вигладити в реченні $C i$ ріжниці пробувано вигладити ріжними поправками, але я вважаю се зайвим (Т. 2, с. 182-183). У реченні Можллив, щзо написано ї̈ зараз же по смерті Войшелка, але рік його смерті не відомий докладно (Т. 3, с. 189) безособова форма дієслова написано виконує синтаксичну функцію співвідносного з присудком головного члена частини складного речення, побудованої за моделлю простого односкладного. Безособове одновалентне дієслово написано не потребує підмета, але прогнозує обов'язкову синтаксичну позицію для додатка, вираженого граматичною формою займенника в знахідному (родовому) відмінку. Як бачимо, категоріальна семантика безособового дієслівного предиката впливає на його здатність прогнозувати обов'язкові валентні позиції. У філологічному тексті кінця XIX - початку XX століття валентність предикатів, виражених безособовою формою дієслова, зумовлює обов'язкову синтаксичну позицію для додатка, як правило, у родовому і знахідному відмінках: $B$ битві побіджено Мстислава, $і$ багато воӥв його побито, город взято й запалено, а єпископа лишили живого й вели до Глухова (Т. 3, с. 204), рідше - в орудному Та вже соколам приборкані крила поганськими шаблями, а самих опутано путами залізними (Т. 2, с. 185). Інколи валентність предикативних форм на -но, -то прогнозують синтаксичну позицію для обставини: Ніхто не міг сказати нічого певного про час рукописи, котру в передмові видання 1800 р. схарактеризовано голим словом, що вона «по своему почерку весьма древняя» (Т. 2, с. 169).

Отже, семантичний потенціал дієслова розкривається у лексикосинтаксичній сполучуваності. Ці лексеми можуть виконувати будь-яку синтаксичну функцію в реченні, але первинною для дієслова $є$ функція присудка або головного члена односкладного речення. У цих предикативних позиціях реалізується семантична природа і валентні потенції дієслова. На основі реалізації його активної валентності відкриваються обов'язкові семантичні позиції для інших компонентів речення.

\section{Література}

1. Вихованець I. Р.Граматика української мови. Синтаксис : [підручник] / Іван Романович Вихованець. - К. : Либідь, 1993. - 368 с.

2. Вихованець I. Р. Частини мови в семантико-граматичному аспекті / Іван Романович Вихованець. - К. : Наукова думка, 1988. - 256 с.

3. Гак В. Г. К типологии функциональных подходов к изучению языка/ Владимир Григорьевич Гак // Проблемы функциональной грамматики. - М. : Наука, 1985. - С. 7. 
4. Гумбольдт В. Избранные труды по языкознанию / Вильгельм фон Гумбольдт; [пер. с нем. яз., ред. и предисловие Г.В. Рамишвили]. - М. : Прогресс, 1984. $400 \mathrm{c}$.

5. Золотова Г. А. Очерк функционального синтаксиса русского языка / Галина Александровна Золотова. - М. : Наука, 1973. - 351 с.

6. Іваницька Н. Б. Абсолютивно-релятивний потенціал українських дієслів у проекції на структуру речення / Наталя Борисівна Іваницька // Acta universitatis palackianae olomoucensis facultas philosophica Ucrainica II. Současná ukrajinistika problèmy jazyka, literatury a kultury. Sbornik člankú. 1. Část. Olomouck, 2006. - C. 269-274.

7. Іваницька Н. Л. Двоскладне речення в українській мові / Ніна Лаврентіївна Іваницька. - К. : Вища школа, 1986. - 168 с.

8. Касымова О. П. Позиция, функция и валентность как системные понятия / Ольга Павловна Касымова // II Международные Бодуэновские чтения: Казанская лингвистическая школа: традиции и современность (Казань, 11-13 декабря 2003 г.): Труды и материалы: в 2 т./ Под общ. ред. К.Р. Галиуллина, Г.А. Николаева. - Казань : Изд-во Казан. ун-та, 2003. T.1. - С. 49-51.

9. Леута О. І. Валентнісно-інтенційні характеристики як основа сполучуваності дієслів у складі синтаксичних структур / Олександр Іванович Леута // Проблеми граматики і лексикології української мови: [зб. наук. праць]; відп. ред. А. П. Грищенко - К., 1998. - С. 25-31.

10. Масицька Т. Є. Граматична структура дієслівної валентності / Тетяна Свгеніївна Масицька. - Луцьк: Волин. держ. ун-т ім. Лесі Українки, 1998. - 207 c.

11. Теньер Л. Основы структурного синтаксиса / Люсьен Теньер; [пер. $з$ франц. И. М. Богуславського; вступ. ст. и общ. ред. В. Г. Гака]. - М. : Прогресс, 1988. - 656 с. - (Языковеды мира).

12. Українська мова: Енциклопедія / редкол.: Русанівський В. М. (співголова), Тараненко О. О. (співголова), Зяблюк М. П. та ін. -[ 2-ге вид., випр. і доп.]. К. : Укр. енциклопедія, 2004. - 824 с.

Грушевський M. С. Історія української літератури: у 6-и томах / Михайло Сергійович Грушевський. - Київ-Львів: Державне вид-во України, 1923-1928. 